\title{
The First One Hundred Open Heart Surgeries in King Abdulaziz University Hospital
}

\author{
Husain H. Jabbad, FRCS(C) and Khaled E. Al Ebrahim ${ }^{1}, \operatorname{FrCS(C)}$ \\ Department of Surgery, Faculty of Medicine \\ King Abdulaziz University, Jeddah, Saudi Arabia \\ dr.k-e@hotmail.com
}

\begin{abstract}
In this paper, the first one hundred open heart surgeries done in King Abdulaziz University Hospital are studied and analyzed, with details of the surgical technique, patient criteria and follow-ups. These cases included coronary, valvular, and congenital cardiac procedures.
\end{abstract}

Keywords: Open heart surgery, King Abdulaziz University Hospital.

\section{Introduction}

Establishing a new cardiac program is costly and challenging to any hospital administration and medical staff. Cardiac surgery is well known as a fine sophisticated art that requires the cooperation of different multidisciplinary services. These include well-trained and experienced cardiac surgeons, noninvasive and interventional cardiologists, cardiac anesthesia and intensive care unit (ICU). The availability of professional nursing staffs especially in the operating room, ICU and the wards is very crucial. Also physiotherapy, blood bank and other medical and surgical subspecialties are important supportive services for this highly demand and comprehensive surgery. The success of these programs depends on achieving favorable results, at least comparable to international standards, initiation of research projects and promotion of medical education and training.

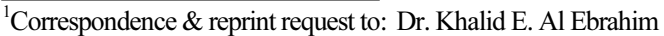

P.O. Box 80215, Jeddah 21589, Saudi Arabia

Accepted for publication: 09 June 2008. Received: 18 February 2008.
} 


\section{Materials and Methods}

Our first 100 cases were operated on nonselective, most of them were coronaries (72) admitted to King Abdulaziz University Hospital's ICU with unstable angina or myocardial infarction, diagnosed and catheterized by our cardiologists, few were referred to us from outside. All cases were accepted, studied and entered in the society of thoracic surgery database. Preoperative assessment and risk stratification using Euroscore were calculated ${ }^{[1]}$ : Thirteen $(18 \%)$ patients had left ventricular function less than $30 \%$. Diabetics were $24(32 \%)$ patients, $18(25 \%)$ hypertensive's, $43(60 \%)$ smokers, hypercholesterolemia in $28(39 \%)$ patients, and elevated renal functions in $9(12 \%)$.

All coronary surgeries were done on cardiopulmonary bypass with blood cardioplegia (cardiac arrest). Pulmonary artery catheters were inserted in patients with poor left ventricular function. All patients received at least one mammary artery except one, a 82-years-old female presented with myocardial infarction complicated with frequent ventricular fibrillation. Patients were monitored in ICU and transferred to the cardiac ward (telemetry unit) after extubation and stabilization. Postoperative physiotherapy and cardiac rehabilitation were continued in the ward. Coronary patients were given their antiplatelets drug, betablockers, angiotensin converting enzyme inhibitors; and an anti diabetic and cholesterol lowering agents while valve patients were anticoagulated with low molecular weight heparin and warfarin.

Most of the valve patients were rheumatic. Different valve procedures were done, repair or replacement using either tissue or mechanical valves.

There were only 4 congenital cardiac procedures; 3 emergency cases; 24 urgent cases most of them are either left main disease or a persistent chest pain. The data and patient criteria of the first one hundred cases are summarized in Tables 1, 2 and 3.

\section{Results}

There were no intraoperative mortality, two early deaths one due to low cardiac output state and the other due to massive cerebral infarction post emergency coronary bypass for left main disease. One late death 
was due to prolonged ventilation secondary to pulmonary fibrosis. The morbidity included one post-operative bleeding requiring surgical exploration, one deep sternal wound infection, four superficial wound infections mainly in the leg treated conservatively. All infection cases were diabetics, 5 cases had perioperative MI, with rising of cardiac enzymes and troponin, 2 of them showed new ECG changes. Intraortic balloon pump was used in four cases to help weaning of the cardiopulmonary bypass, one of them required left ventricular assist device. Three cases developed post-operative transient atrial fibrillation responded to amiodarone infusion. One case developed subclavian vein thrombosis predisposed by the central line, and treated with anticoagulation. These results are summarized in Table 4.

Table 1. Data shows 72 coronary patients who underwent open-heart surgery in King Abdulaziz University Hospital.

\begin{tabular}{l|c}
\hline \multicolumn{1}{c|}{ Coronary graft patients } & $\begin{array}{c}\text { Patients } \\
(\mathbf{n}=\mathbf{7 2})\end{array}$ \\
\hline \multicolumn{1}{c}{ Patient's criteria } \\
\hline Age: 59-82 years (mean 67) \\
\hline Sex: \\
\hline Male \\
\hline Female \\
\hline Type: \\
\hline Acute Coronary Syndrome \\
\hline Diabetes Mellitus & 26 \\
\hline Hypertension & 43 \\
\hline Cerebrovascular accident & 24 \\
\hline Dyslipidemia & 18 \\
\hline Renal impairment & 4 \\
\hline
\end{tabular}

Table 2. Number of coronary grafts done.

\begin{tabular}{c|r}
\hline \multicolumn{2}{|c}{ Number of coronary grafts } \\
\hline $\mathrm{CABG} \times 1:$ & 2 \\
\hline $\mathrm{CABG} \times 2:$ & 3 \\
\hline $\mathrm{CABG} \times 3:$ & 24 \\
\hline $\mathrm{CABG} \times 4:$ & 38 \\
\hline $\mathrm{CABG} \times 5:$ & 4 \\
\hline $\mathrm{CABG} \times 6:$ & 1 \\
\hline
\end{tabular}


Table 3. Data shows 26 valvular, congenital and emergency cases that underwent openheart surgery in King Abdulaziz University Hospital.

\begin{tabular}{l|c}
\hline \multicolumn{1}{c|}{ Open heart surgery procedures } & Cases \\
\hline Valve Surgery & 22 \\
\hline AVR & 5 \\
\hline MVR & 7 \\
\hline Mitral Valve (MV) repair & 3 \\
\hline AVR+MVR & 4 \\
\hline Redo valve surgery & 1 \\
\hline Combined CABG + valve & 2 \\
\hline Congenital Heart Surgery & 4 \\
\hline Repair of ASD secondum: (pericardial patch) & 3 \\
\hline Repair of discrete SAM $\quad$ Emergency cardiac surgery & 1 \\
\hline Ascending. Aortic aneurysm repair (Bentall): & 1 \\
\hline Ruptured VSD, post MI: & 1 \\
\hline Myocardial infarction in evolution & 1 \\
\hline
\end{tabular}

AVR (Aortic Valve Replacement); MVR (Mitral Valve Replacement); ASD (Atrial Septal Defect), SAM (subaortic membrane), CABG (coronary artery bypass grafting), MI (myocardial infarction), VSD (ventricular septal defect).

Table 4. Results of operation in the first one hundred open heart surgeries in KAUH.

\begin{tabular}{|c|c|}
\hline $\begin{array}{lll}\text { Mortality: } & \begin{array}{l}\text { Operative } \\
\text { Post operative: Early } \\
\end{array} \\
& \\
\text { Late }\end{array}$ & $\begin{array}{l}0 \\
2 \\
1\end{array}$ \\
\hline $\begin{array}{c}\text { ICU Stay } \\
\text { Hospital Stay }\end{array}$ & $\begin{array}{c}\text { 2-6 (mean, } 3) \text { days } \\
\text { 7-30 (mean, } 11) \text { days }\end{array}$ \\
\hline Ventilation Hours & 4- 42 (mean 8.4) hours \\
\hline $\begin{array}{l}\text { Complications: } \\
\text { Perioperative MI } \\
\text { Intra Aortic Balloon Pump (IABP) }\end{array}$ & $\begin{array}{c}(\mathrm{n}=\text { Cases }) \\
5 \\
\quad 4\end{array}$ \\
\hline $\begin{array}{l}\text { Arrhythmias: } \\
\text { Atrial Fibrillation (AF) } \\
\text { Bleeding (requiring exploration) } \\
\text { Cardiac Tamponade } \\
\text { Wound Infection } \\
\text { Superficial wound infection }\end{array}$ & $\begin{array}{c}3 \\
1 \\
\text { None } \\
4\end{array}$ \\
\hline $\begin{array}{l}\text { Chest: } \\
\text { Lower limb: } \\
\text { Mediastinitis and Sternal Dehiscence } \\
\text { Cerebrovascular Accident (CVA) } \\
\text { Psychosis } \\
\text { Deep Vein Thrombosis (subcalvian) } \\
\text { Pleural Effusion (significant requiring chest tube insertion) } \\
\text { Tracheotomy }\end{array}$ & $\begin{array}{l}1 \\
3 \\
1 \\
1 \\
1 \\
1 \\
3 \\
1\end{array}$ \\
\hline
\end{tabular}




\section{Discussion}

Cardiac diseases, especially coronary artery disease, are nowadays a rising trend. This is attributed to the increasing incidence of atherosclerotic risk factors in the Saudi population ${ }^{[2]}$. Obesity and overweight prevalence are exceeding $35.5 \%{ }^{[2,3]}$, adult onset diabetes affecting at least $24 \%^{[2,4]}$, and hypertension in about $2 \%^{[2,5]}$. The prevalence of coronary artery disease among hypertensive patients is about $8.2 \%{ }^{[5]}$. The dramatic increase of hypercholesterolemia, affecting about $45 \%$ of the Saudi population is secondary to change in life style and food habits ${ }^{[2,3]}$.

All our cases were accepted for surgery non-selectively as soon as it was referred from our cardiologist. Clopidogrel is stopped at least 5 days prior to elective procedures. Cardiac surgeons are faced with progressing higher risk challenging cases; only difficult cases not suitable to interventional cardiology were referred to the surgeons. These included elderly patients with small vessels, multiple distal disease and poor left ventricular function. These will add to the difficulty facing new small cardiac units.

The results of these 100 cases presented are, in general, good and encouraging as it is comparable to the local international standards ${ }^{[6]}$.

In the management of our patients, we have taken up many new modalities of treatments, which have proven clinical or experimental benefits. The use of blood cardioplegia is an expanding subject in cardiac surgery, and many studies have documented its superiority over crystalloid cardioplegia. The use of aprotinin, epsilon-aminocaproic acids, and Tranexamic acid have helped in reducing the intraoperative and postoperative blood loss, and the need for blood transfusion ${ }^{[7]}$. Exchange transfusions in patients with sickle cell disease have proved to be effective, and also hemofiltration on cardiopulmonary bypass in general and in the impairment of renal function ${ }^{[8,9]}$.

Three very high-risk cardiac cases were done successfully in the unit. The first was an ascending aortic aneurysm, about $13 \mathrm{~cm}$, underwent composite valve graft conduit with coronary implantation. The second was Dacron patch of post infarction interventricular septum rupture and the third was primary repair of a complete sternal cleft using titanium plates and screws. 
Our future prospective will focus on expanding our open-heart workload, establishing a combined hybrid cardiology cardiac surgery service, and starting a pediatric cardiac surgery program.

\section{References}

[1] Roques F, Michel P, Goldstone AR, Nashef SA. The logistic EuroSCORE. Eur Heart J 2003; 24(9): 881-882.

[2] Osman AK, Al-Nozha MM. Risk factors of coronary artery disease in different regions of Saudi Arabia. East Mediterr Health J 2000; 6(2-3): 465-474.

[3] Al-Nuaim AR, Al-Rubeaan K, Al-Mazrou Y, Al-Attas O, Al-Daghari N. Prevalence of hypercholesterolemia in Saudi Arabia, epidemiological study. Int J Cardiol 1996; 54(1): 41-49.

[4] Al-Nozha MM, Al-Maatouq MA, Al-Mazrou YY, Al-Harthi SS, Arafah MR, Khalil MZ, Khan NB, Al-Khadra A, Al-Marzouki K, Nouh MS, Abdullah M, Attas O, AlShahid MS, Al-Mobeireek A. Diabetes mellitus in Saudi Arabia. Saudi Med J 2004; 25(11): 1603-1610.

[5] Al-Nozha MM, Abdullah M, Arafah MR, Khalil MZ, Khan NB, Al-Mazrou YY, AlMaatouq MA, Al-Marzouki K, Al-Khadra A, Nouh MS, Al-Harthi SS, Al-Shahid MS, Al-Mobeireek A. Hypertension in Saudi Arabia. Saudi Med J 2007; 28(1): 77-84.

[6] Al-Ebrahim KH, Otoole J, El-Shafei H. The first 100 cases of open heart surgery at Al Hada Cardiac Center: review of results. J Saudi Heart Assoc 1994; 6(1): 15-17.

[7] Landymore RW, Murphy JT, Lummis H, Carter C. The use of low-dose aprotinin, epsilon-aminocaproic acid or tranexamic acid for prevention of mediastinal bleeding in patients receiving aspirin before coronary artery bypass operations. Eur J Cardiothorac Surg 1997; 11(4): 798-800.

[8] Raman JS, Hata M, Bellomo R, Kohchi K, Cheung HL, Buxton BF. Hemofiltration during cardiopulmonary bypass for high-risk adult cardiac surgery. Int J Artif Organs 2003; 26(8): 753-757.

[9] Black HA, Dearing JP. Exchange transfusion prior to cardiopulmonary bypass in sickle cell anemia. J Extra-Corpr Technol 1980; 12: 82-85. 
أول مائة جر احة قلب مفتوح بمستشفى جامعة الملك عبدالعزيز

$$
\begin{aligned}
& \text { حسين حمزة جباد، و خالد إبراهيم آل إبر اهيم } \\
& \text { قسم الجر/حة، كلبة الطب ، جامعة الملك عبدالعزيز }
\end{aligned}
$$

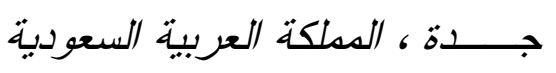

المستخلص. نبذة مختصرة ووصف تحليلي لأول مائة جر احة قلب

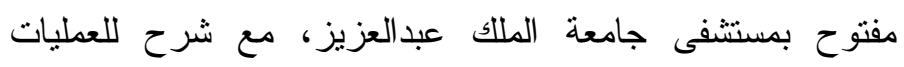

الجر احية، وتصنيف المرضى. تشمل حالات شر ايين القلب التاجية

و الصمامات و النشو هات الخلقية. 